\title{
DIE VAL VAN PRETORIA
}

Op 9 Oktober 1899 het die Suid-Afrikaanse Republiek, bygestaan deur die susterrepubliek, die Oranje-Vrystaat, 'n ultimatum aan die Britse Regering versend wat uitgeloop het op die Tweede Anglo-Boereoorlog. In die daaropvolgende oorlog het die republieke in die eerste maande heldhaftig hul grense verdedig totdat lord Roberts met ' $n$ sterk troepemag daarin geslaag het om die Boeremagte te ontsetel uit hulle stellings en gaandeweg daarin geslaag het om vanuit die Kaapkolonie noordwaarts op te ruk deur die Vrystaat. Bloemfontein het op 13 Maart 1900 geval en op 24 Mei het lord Roberts aan die Vaalrivier gestaan waar hy by wyse van proklamasie die Oranje-Vrystaat geannekseer het in die naam van Haar Majesteit, koningin Victoria van Engeland. Die spoed waarmee lord Roberts opgeruk het eers na die Bloemfonteinse en daarna na die Transvaalse hoofstede, het die Boeremagte onkant gevang. Binne enkele maande moes hulle telkens van een stelling na die volgende terugval terwyl ruim 4000 burgers uit hul skrale geledere gevange geneem is met die slag van Paardeberg.

Met die Britte op Transvaal se grense was vooruitsigte op 'n spoedige oorwinning skraal en baie burgers wou moedverlore die wyk neem. Ander het pal gestaan want, so het hulle geglo, Pretoria, die hoofstad van Transvaal, sal nie maklik val nie. Daarvoor is hy veels te sterk gefortifiseer.

$\mathrm{Na}$ die Jameson-inval het breedvoerige planne om Pretoria te verower, aan die lig gekom. Vir die ingesetenes sowel as die Volksraad was hierdie feite onrusbarend sodat daarna in erns aandag geskenk is aan die verdediging van Pretoria. Op aanbeveling van ' $n$ kommissie wat oor die aangeleentheid verslag moes lewer, is daar besluit om teen ' $n$ bedrag van $R 516000,00$ ' $n$ versterkte ammunisieopslag-plek en vier forte om Pretoria te bou. Hierdeur is strategiesgeleë koppies om die stad gefortifiseer om die vernaamste poorte wat toegang tot die stad verleen, te beskerm. Die Duitse firma Krupp het forte Schanskop, Klapperkop en Wonderboompoort opgerig terwyl 'n Franse maatskappy, Le Creusot, fort Wesfort (op Daspoortrand) opgerig het. Bergkanonne en ander grofgeskut is bestel vir die forte maar almal was nie voor die uitbreek van die oorlog afgelewer nie. Die doeltreffende funksionering van die forte is verhoog deurdat ' $n$ telegraafnetwerk behoorlike kommunikasiefasiliteite vir die bemanning verseker het. ${ }^{1}$

In sommige kringe is die groot koste verbonde aan die oprigting van die forte heftig gekritiseer maar toe die oorlog uitbreek, was dit die algemene gevoel onder die burgers dat daar veiligheid en sekuriteit gewaarborg was in die sterk gefortifiseerde Pretoria. Wat lord Roberts en die meeste burgers in die veld egter nie geweet het nie, is dat met die verloop van die oorlog mettertyd grofgeskut sowel as bemanning uit die forte onttrek is sodat die vestingwerke teen die einde van Mei 1900 inderdaad skadeloos was. Terwyl die burgers dus die vyand tydens sy opmars na Johannesburg orals voorgelê het en sy vooruitgang so ver moontlik vertraag het, het hulle heimlik vooruitgesien na die groot slag wat sou plaasvind in die randjies en deinveld om Pretoria.

In die hartjie van die hoofstad was daar op hierdie stadium egter gewaarwordings aan die roer wat presies net die teenoorgestelde gedagtes laat ontstaan het. Op Maandag $7 \mathrm{Mei}$ toe die Suid-Afrikaanse Republiek se Volksraad vir die laaste keer in die hoofstad byeen gekom het, was dit diep onder die besef van kanongebulder digby Transvaal se grense wat die afgevaardigdes hulle plekke in die Raadsale ingeneem het. Tog het oorlogstoestande geen afbreuk gedoen aan die seremoniële wyse waarop hierdie gebeurtenis, soos talle tevore, aangepak is nie. In die Eerste Volksraad het die voorsitter, genl Lucas Meyer die verrigtinge geopen. Daar was 'n klomp leë stoele in die Raadsaal: genls L. Botha, Koos de la Rey en S. J. du Toit en raadslid Stoop was afwesig op komman'dodiens terwyl genl P. Cronje reeds krygsgevange geneem was. Sy stoel is vir die byeenkoms met die 
vierkleur gedrapeer. Die stoele van die eertydse vise-president, kmdt genl Piet Joubert, genl J. H. M. de Kock, uitvoerende raadslid Barnard en raadslid Tosen was vir altyd leeg. ${ }^{2}$ Die oorlog het op kennelike wyse in die hart van die regering self sy slagoffers geëis. Tog moet die werksaamhede van die Raad voortgaan en afgevaardigdes is oudergewoonte benoem om Sy Edele, President S. J. P. Kruger, na die opening van die volksraadsitting om $3 \mathrm{~nm}$ geleide te doen. Ds H. S. Bosman is amptelik versoek om die vergadering met gebed te open en die lede van die Tweede Volksraad is soos gewoonlik ook uitgenooi om die opening by te woon. ${ }^{3}$

Raadslede P. J. Schutte, D. J. Louw en W. H. van Niekerk het die eer te beurt geval om die gryse president tydens sy laaste opening van die Volksraad in die Raadsaal op Kerkplein, Pretoria, geleide te doen. ${ }^{4}$

Aan luister het dit nie ontbreek nie. Die president het per koets by die saal gearriveer en die Raadsaal van die Eerste Volksraad binnegegaan waar raadslede, buitelandse verteen- woordigers, en ander amptenare en belangstellendes byeengekom het om na sy openingsrede te luister. Sy toespraak in hierdie donker uur van sy volk se geskiedenis toon 'n intense bewustheid van die offers wat gevra word. Hy verduidelik dat uit dokumentêre bewyse in besit van die regering dit vir hom duidelik geword het dat die oorlog onvermydelik was. Oor die stemregkwessie, waarvan lord Milner en mnr Joseph Chamberlain in die laaste dae voor die oorlog so baie gewag gemaak het, het hy tot die slotsom gekom dat, 'Al het ons 1 jaar gegee, sou dit nie aangeneem werd.' Die enigste troos en bemoediging wat die gryse president toe aan sy volk kon gee, was om nie te wanhoop nie maar om in God te glo. ${ }^{5}$

Die sitting het slegs drie dae geduur. Volksraadslid en landsburger kon eweneens aan niks anders dink en oor niks anders praat nie as die oorlog. Van die barbaarse oorlogspraktyke van die vyand is by herhaling gewag gemaak. Baie was reeds in rou gedompel; ander weer bekommerd oor bloedver-

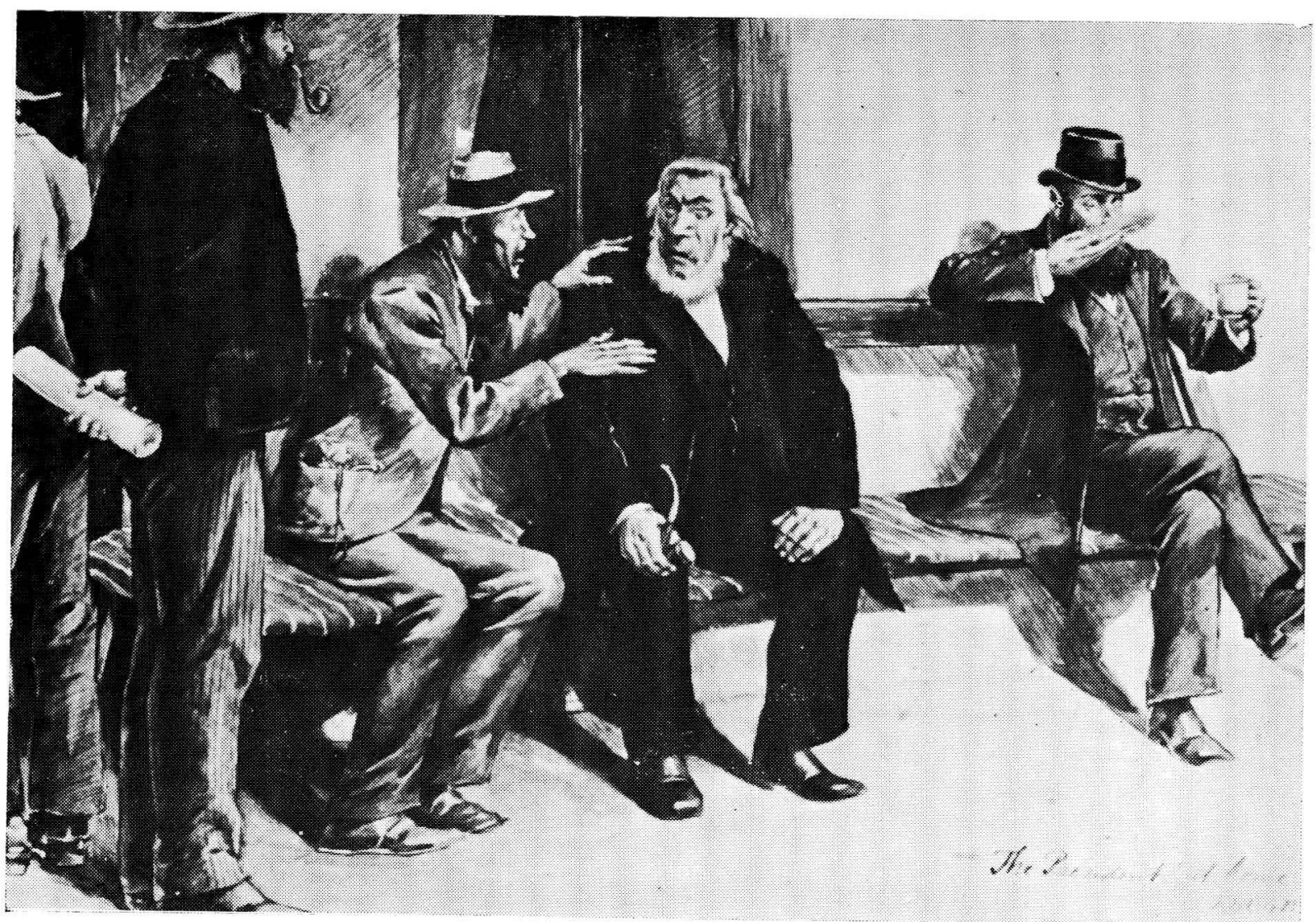

'n Voorstelling van die kunstenaar C. E. Fripp van President Kruger se besoekers, 1900

(Foto: Africana Museum) 
wante wat 'oor die see' verskeep is na afsondering in ' $n$ vreemde land terwyl 'n aantal verongenoegdes sondebokke gesoek het vir die ellende waarin hulle skielik gedompel is. Daar was ook 'n sterk gevoel onder die publiek, gesteun deur staatsekretaris F. W. Reitz en die staatsmyningenieur J. H. Munnik, om die Johannesburgse goudmyne op te blaas want, so het hulle gesê: 'Dit is mos die kapitaliste se skuld dat ons in oorlog gedompel is!' Hulle het ork 'n pamflet, getitel Bezint eer gij begint versprei waarin, aldus De Volkstem van 15 Mei 1900 'gepoogd wordt om argumenten bij te brengen tegen een eventuele onbruikbaarmaking onzer goudmijnen.' Hierdie planne is deur die tydige tussenkoms van waarnernende kmdt genl $L$. Botha in die wiele gery. ${ }^{6}$

\section{Die front skuif nader}

Intussen het die handelaars wat oor groot voorraadskure beskik het, in spanning gelewe want 'n aanval op Pretoria kon maklik groot finansiële verliese vir hulle tot gevolg hê. Aan genl S. Burger, bygestaan deur 'n kommissie, is opdrag gegee om Pretoria se verdedigingstelsel te organiseer maar hy - en talle ander - was so besorgd oor ander probleme dat daar oënskynlik hoegenaamd niks daadwerkliks in die verband gedoen is nie. Hy het trouens ook nie genoeg tyd gehad om veel te vermag nie. ${ }^{7}$

Die daaglikse lewe in Pretoria het sy gang gegaan en niemand het op 15 Mei daaraan gedink dat lord Roberts voor die einde van die maand in Johannesburg sal wees nie. In die $u$ andel is daar met verontwaardiging gewag gemaak van die talle moedelose burgers wat van tyd tot tyd hul opwagting in Pretoria gemaak het. Teenoor diegene wat gepraat het van wapens neerlê, het andere gestaan wat verontwaardig uitgeroep het: 'Ach, hoe vernederend voor ons volk. En wat zal de buitenwêreld . . . nu wel van die Afrikaner helden-natie denken.' Ander het weer gewonder hoe afstammelinge van die 'kloeke Voortrekkers so wankelmoedig' kan wees. ${ }^{8}$ Daar is selfs voorgestel dat oorlewende Voortrekkers na die front gestuur moes word om die moreel op te bou. As hierdie tendens ' $n$ bron van kommer was, het dit die daaglikse lewe nie veel beïnvloed nie. Sosiale aktiwiteite het normaalweg verloop. So het 'n sekere mej

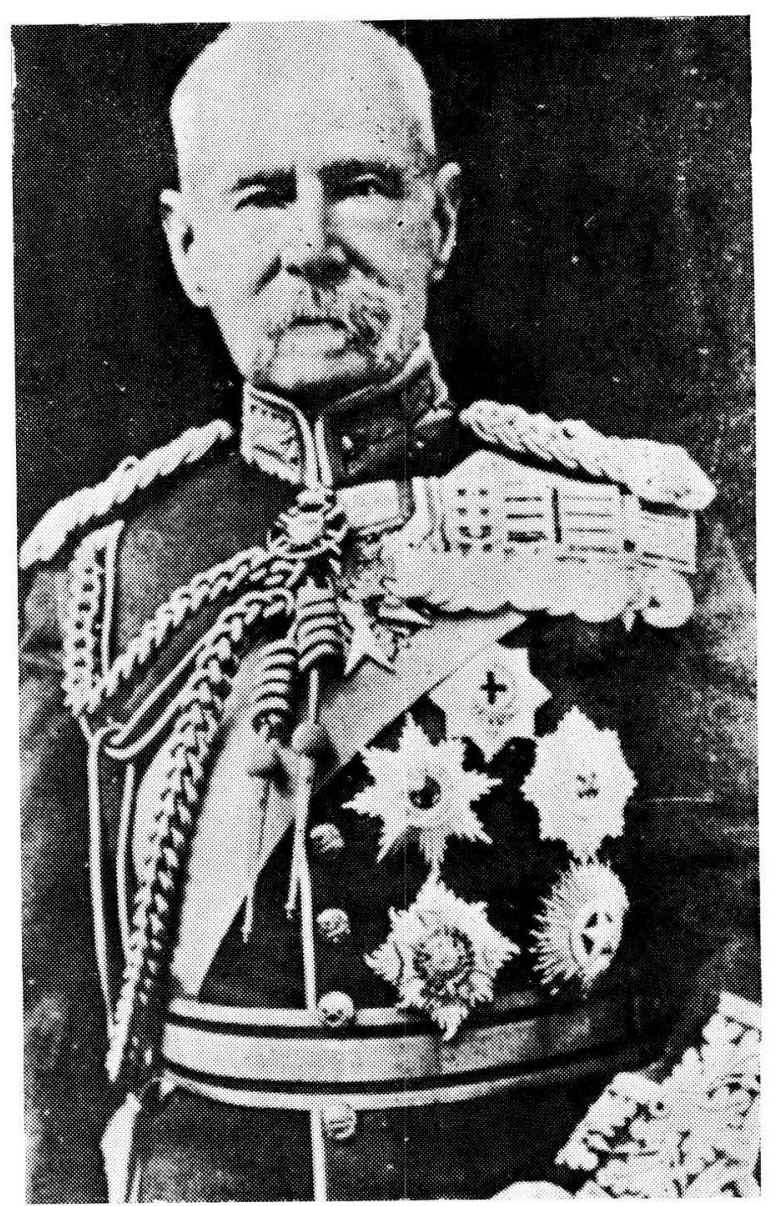

Lord Roberts

Van der Hoven onderneem om 'n liefdadigheidskonsert in St Andrews Hall te hou op 25 Mei. ${ }^{9}$ Almal het hulself veilig gewaan in die hoofstad veral nadat ' $n$ besielde burger vanaf die front vol selfvertroue aan die redaksie van De Volkstem verklaar het dat 'de Vaalrivier . . voor de moede Engelse soldaat . . . een vreselijke positie (sal) blijken te zijn en ongetwyfeld zal binnen weinig dagen de natuurlike zuiderlike grenslijn van die ZAR rood gekleurd zijn van het bloed van de ongelukkige instrumenten in de handen van de tegenwoordige Engelse politici'. ${ }^{10}$

Ondanks die moedeloosheid van sommige burgers, was die tuisblyers oënskynlik houtgerus en nog baie veglustig. Van die skoner geslag het selfs gespeel met die gedagte om 'n vrouekommando op die been te bring: iets waarvan die plaaslike mans nie wou hoor nie. Intussen het lord Roberts se lang kollonne met rasse skrede gevorder. Op 25 Mei was die vyand skaars 100 kilometer vanaf Johannesburg. 


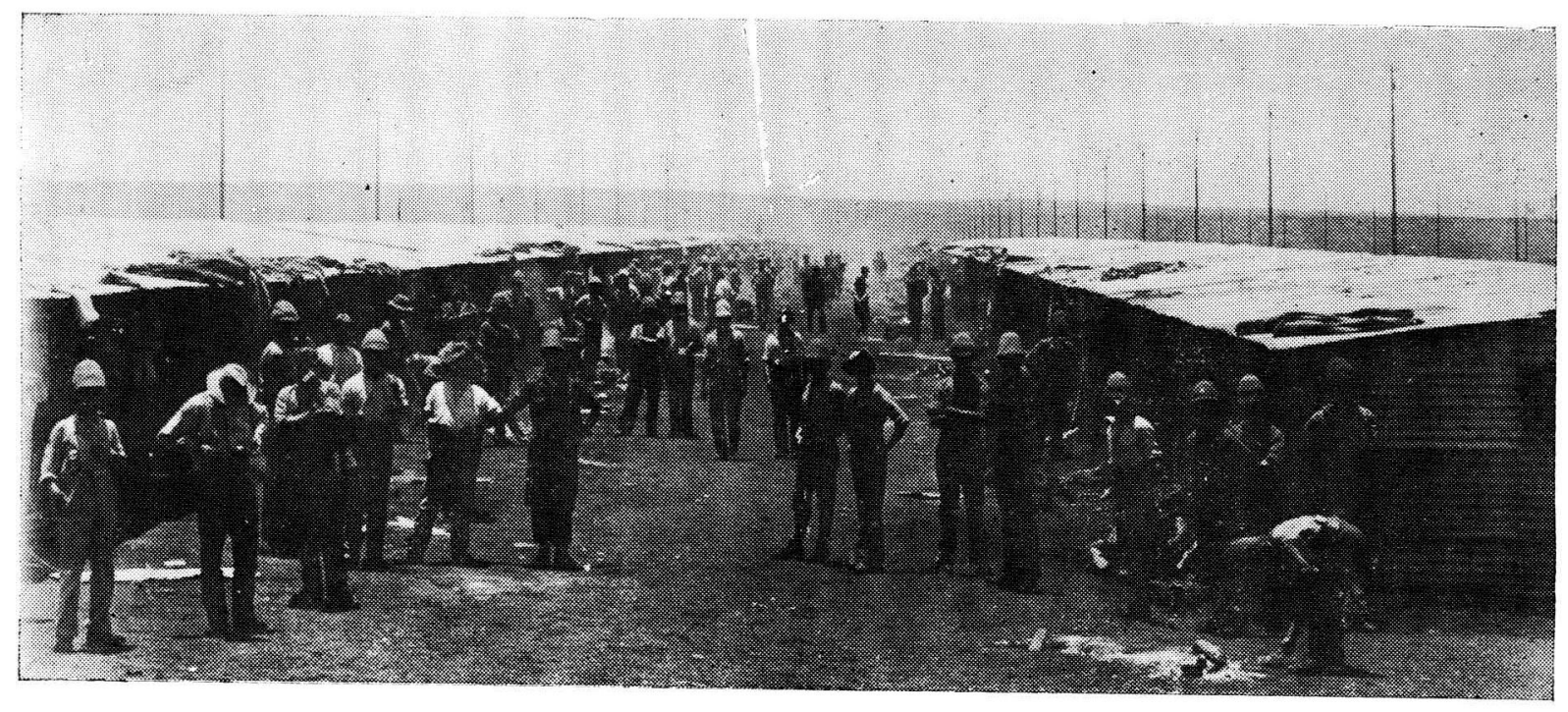

Britse krygsgevangenes in Ladysmithstraat, Waterval

(Foto: Staatsargief, Pretoria)

Op hierdie dag het die Uitvoerende Raad skynbaar vir die laaste keer in Pretoria byeengekom. Inderhaas is 'n kommissie benoem om 'n kamp op Machadodorp te bou vir die Britse krygsgevangenes, op daardie stadium nog gehuisves te Waterval net noord van Pretoria. Dit word hulle op die hart gedruk om 'in dezen alle spoed aan te wend om, indien het noodzakelijk wordt, de krijgsgevangenen zonder verwijl daarheen te kunnen verplaatsen.'11 Die idee was goed maar te laat om te volvoer en slegs 'n negehonderd tot een duisend soldate is betyds verwyder.

Die aand van $29 \mathrm{Mei}$, toe It genl J. D. P. French reeds noordwes van Doornkop by Johannesburg was, het pres Kruger en 'n klompie amptenare stilweg per koets uit Pretoria vertrek na Eerste Fabrieke waar sy spesiale spoorwegwa gereed gestaan het om hom na Machadodorp te vervoer. Die bestuur van die stad is gelaat in die hande van 'n dertigtal prominente inwoners met die handelaar T. W. Beckett, wie se winkel jarelank 'n bekende baken op die hoek van Kerk- en Van der Waltstrate was, as voorsitter. Net voor hul vertrek het genl Lucas Meyer en genl Schalk Burger ' $n$ brief geskryf aan P. J. Potgieter, burgemeester van Pretoria. ${ }^{12}$ Daarin is aan hom opdrag gegee om Pretoria aan die Britte te oorhandig. In dieselfde brief is ook versoek dat hy met die Britse offisiere wat in die Staatsmodelskool in Pretoria gevange gehou is, onderhandel om die 3000 krygsgevangenes by Waterval in bedwang te hou totdat hulle deur die Britte ontset word.

Intussen het genl Botha met skaars 3000 burgers al vegtend en vlugtend teruggeval voor lord Roberts wat op hierdie stadium ruim 20000 man tot sy beskikking gehad het. Nadat die Boeremagte hul linie suid van Johannesburg moes ontruim, het die burgers volgens J. F. Naude wat saam met die latere genls C. F. Beyers en J. C. G. Kemp geveg het, reikhalsend uitgesien na die beskerming wat hul hoofstad sou bied. 'Immers daar waren de kostbare forten rondom, en met die vier groote Creusots daarin en de burgermachten op de randen rondom, welke wij verwachten ook al gefortificeerd te vinden, zou het egter dan een Colenso en Pietershoogte zijn; daarheen trokken de burgermachten nu af.'13

Reeds op Johannesburg moes sommige van hulle die teleurstellende nuus verneem: die forte is sonder hulle Creusot-kanonne. Dit was volgens genl B. Viljoen noodlottig vir waarnemende kmdt genl L. Botha se defensiewe beplanning. Burgers het in toenemende getalle skaamteloos van die kommando's gedros om oor eie huis en haard te waak en groepies mans het te perd in Pretoria begin aankom: party omdat hulle geglo het dat hulle so sou meehelp om die val van Pretoria te voorkom; ander omdat hulle nie meer kon glo in sukses vir die Boeremagte nie; nog andere, soos Deneys Reitz, om voorrade aan te vul vir die verdere stryd. 


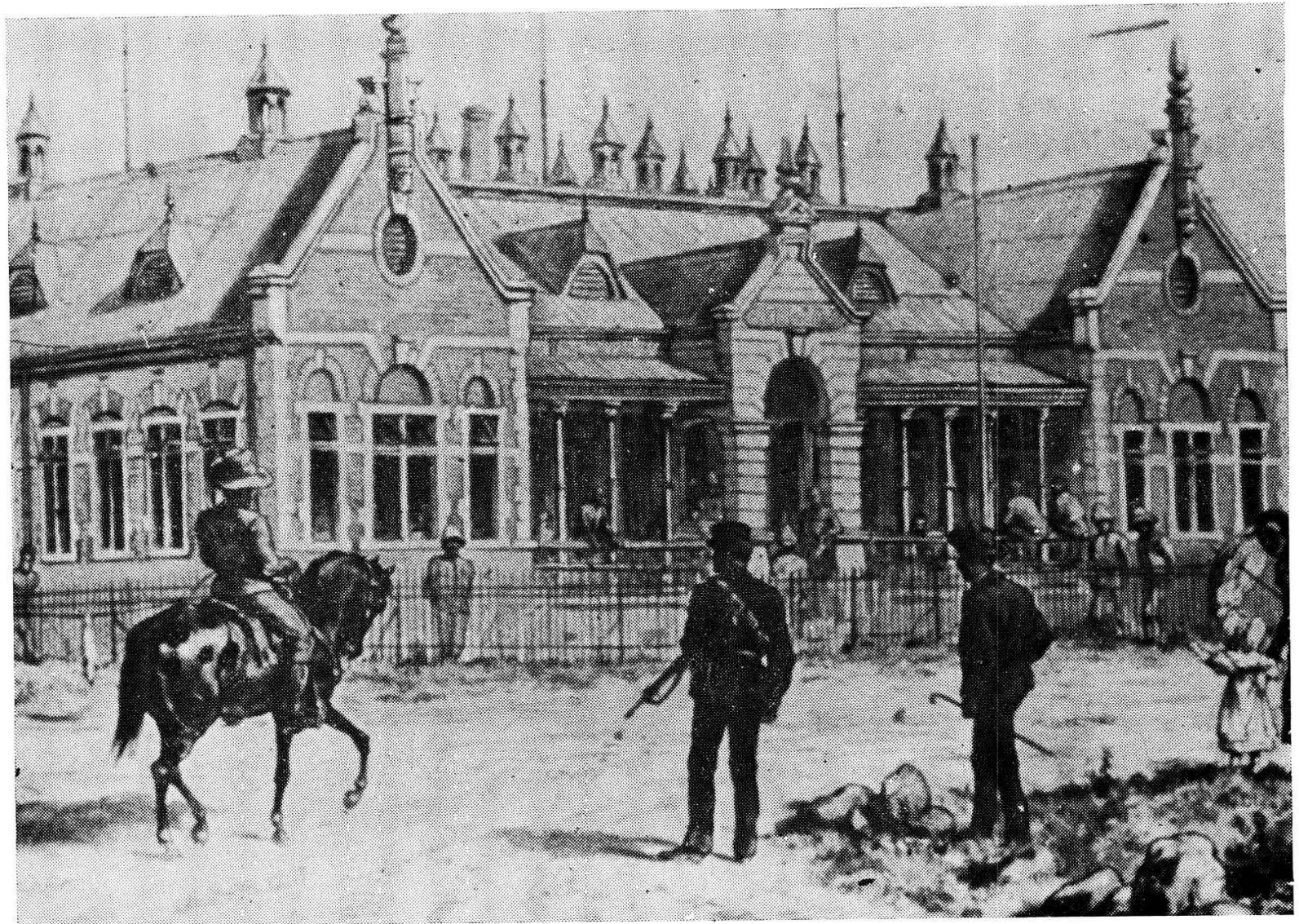

Staatsmodelskool in Pretoria waar Britse krygsgevangenes aangehou is

(Foto: Africana Museum)

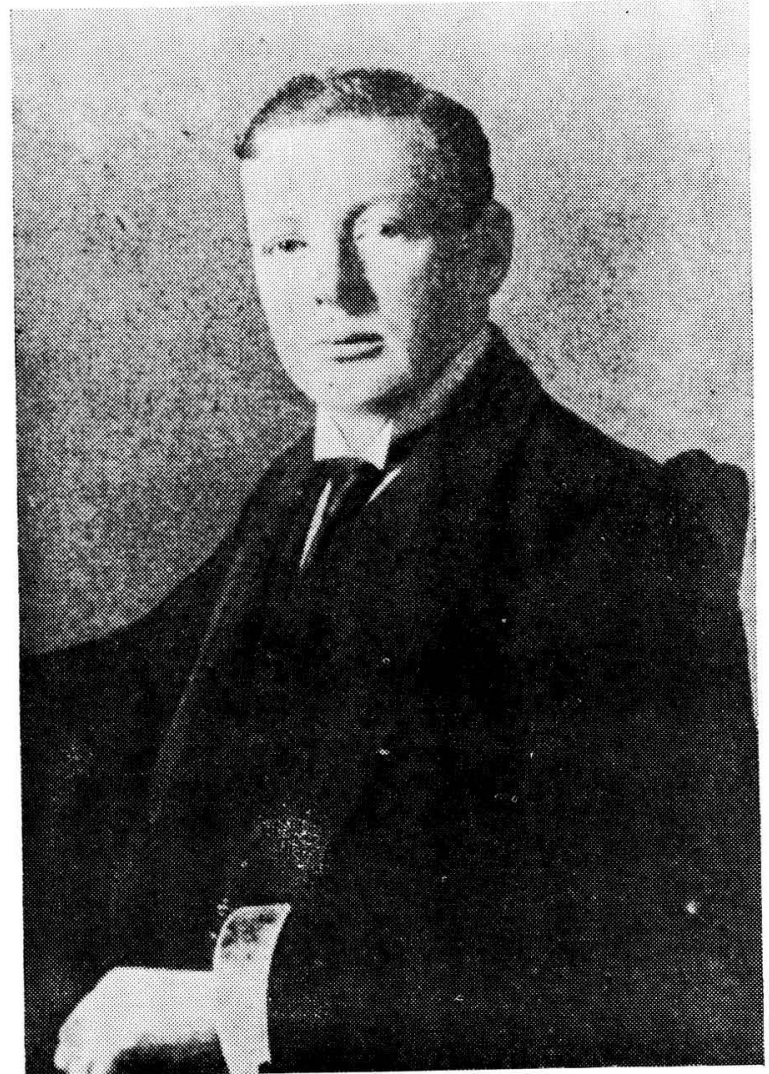

(Foto: Staatsargief, Pretoria) Winston Churchill (later sir), oorlogskorrespondent van die Morning Post wat in die Staatsmodelskool aangehou is en daarin geslaag het om te ontsnap. $\mathrm{Hy}$ is by Chievely deur genl Botha se manskappe gevange geneem

$$
\text { io the Seet fortiar. }
$$$$
01 \frac{9050}{99}
$$

$\sin$

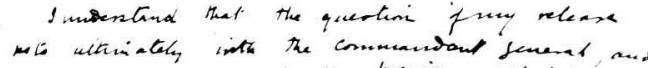

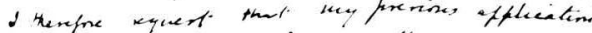

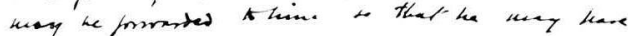

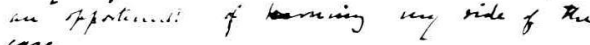

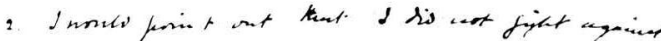

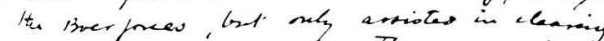$$
\text { He line forne the ditrio. Ahei is previses }
$$

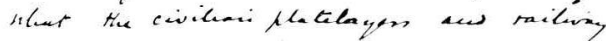

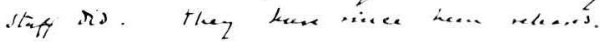

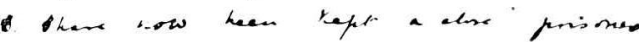$$
\text { for } 24 \text { deng, }
$$

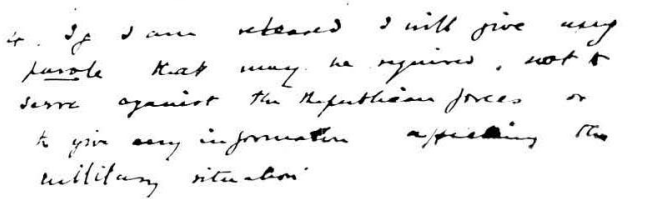$$
\text { Incertio }
$$

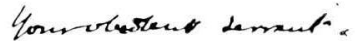

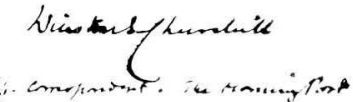

giede.

(Foto: Staatsargief, Pretoria)

'n Pleidooi om vrylating van Winston Churchill gedateer 8 Desember 1900 


\section{Verdediging van Pretoria}

Suid van Pretoria het genl Botha sy kommando's stelling laat inneem om lord Roberts se opmars vanuit Johannesburg te stuit maar die afgelope maande se geskiedenis kon geen ingesetene meer laat twyfel aan die feit dat die vyand binne enkele dae op hul drumpel in Pretoria sou wees nie.

Bowendien was die kmdt genl se beplanning verder in die wiele gery deur pres S. P. J.
Kruger se definitiewe opdrag in die verband. Op 2 Junie 1900 het hy getelegrafeer: 'Om Pretoria te beschermen is goed doch zulks moet vèr langs geschieden en maak het die officieren en burgers op dit punt zeer duidelijk ... en waak toch er voor dat die stad nie gebombardeerd worden want in dat geval waar moeten de onschuldige vrouwen en kinderen dan heen ?'14

Teen die aand van 30 Mei was dit allerweë bekend dat die regering Pretoria verlaat het
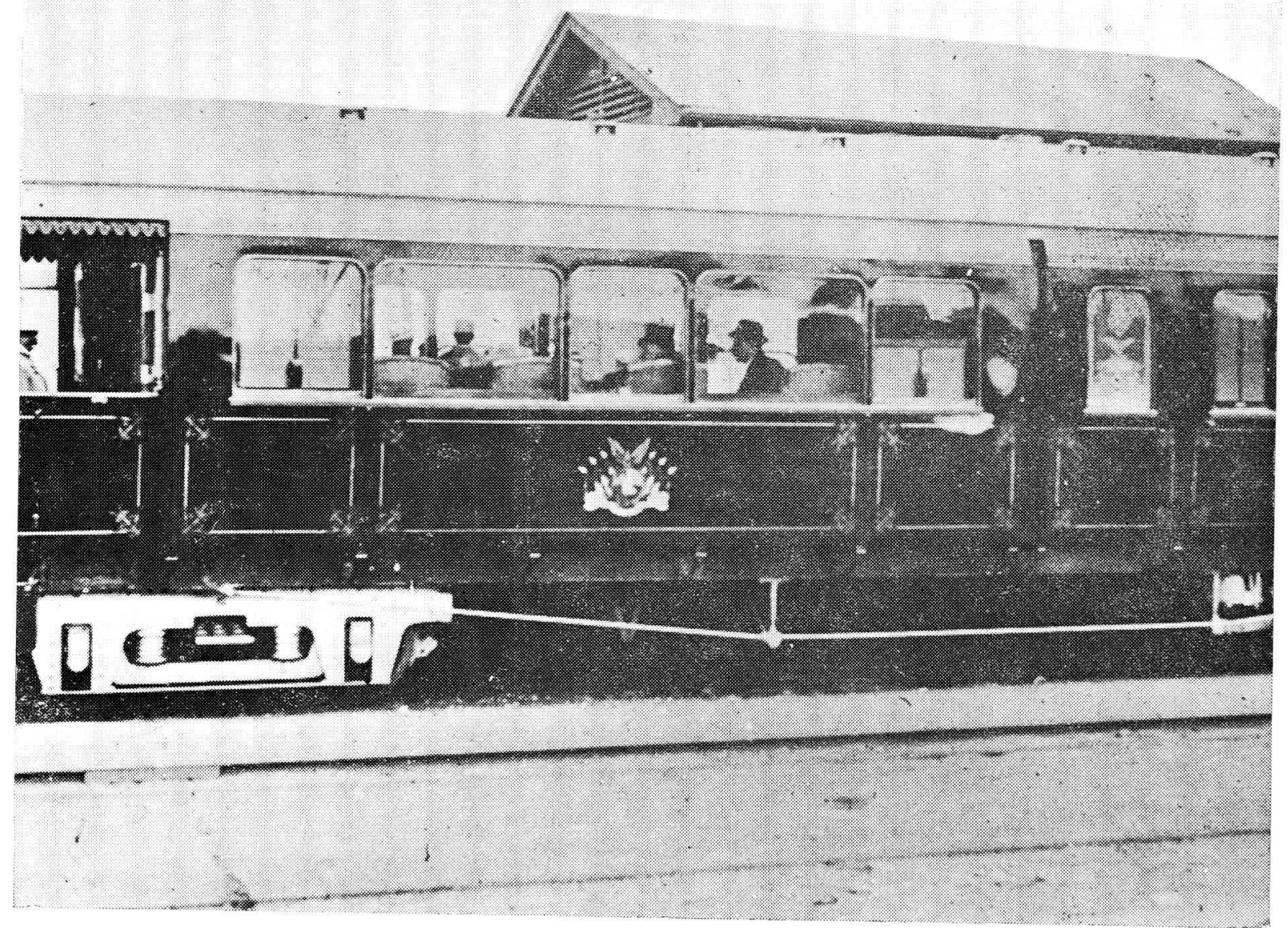

(Foto: Stadsraad,
President Kruger en staatsamptenare in sy salonwa waarmee hy na Machadodorp gereis het

en veilig in die wete dat daar nie 'n gesaghebbende liggaam bestaan om orde te handhaaf nie, het boosdoeners hul kans afgewag.

So het Donderdag 31 Mei 1900 aangebreek: 'n 'swart' dag in die geskiedenis van Pretoria. In die nag inet plunderaars hul kans waargeneem en by die regeringsmagasyn ('n sinkgebou op die hoek van Paul Kruger- en Visagiestrate) ingebreek. Sommige is selfs met die koms van die daglig nie verdryf nie. Van die nuwe rekrute in die polisiemag wat inderhaas saamgestel is, het juis van hul amp gebruik gemaak om aan die kwaad mee te doen. ${ }^{15}$

Allerlei gerugte het dié wat daaraan geglo het, paniekbevange gemaak. So was gerugte van die afbranding van huise wat op lord Roberts se bevel geskied het en ander barbaarse oorlogspraktyke van die vyand van huis tot huis oorgedra - 'n bron van kommer vir menige 


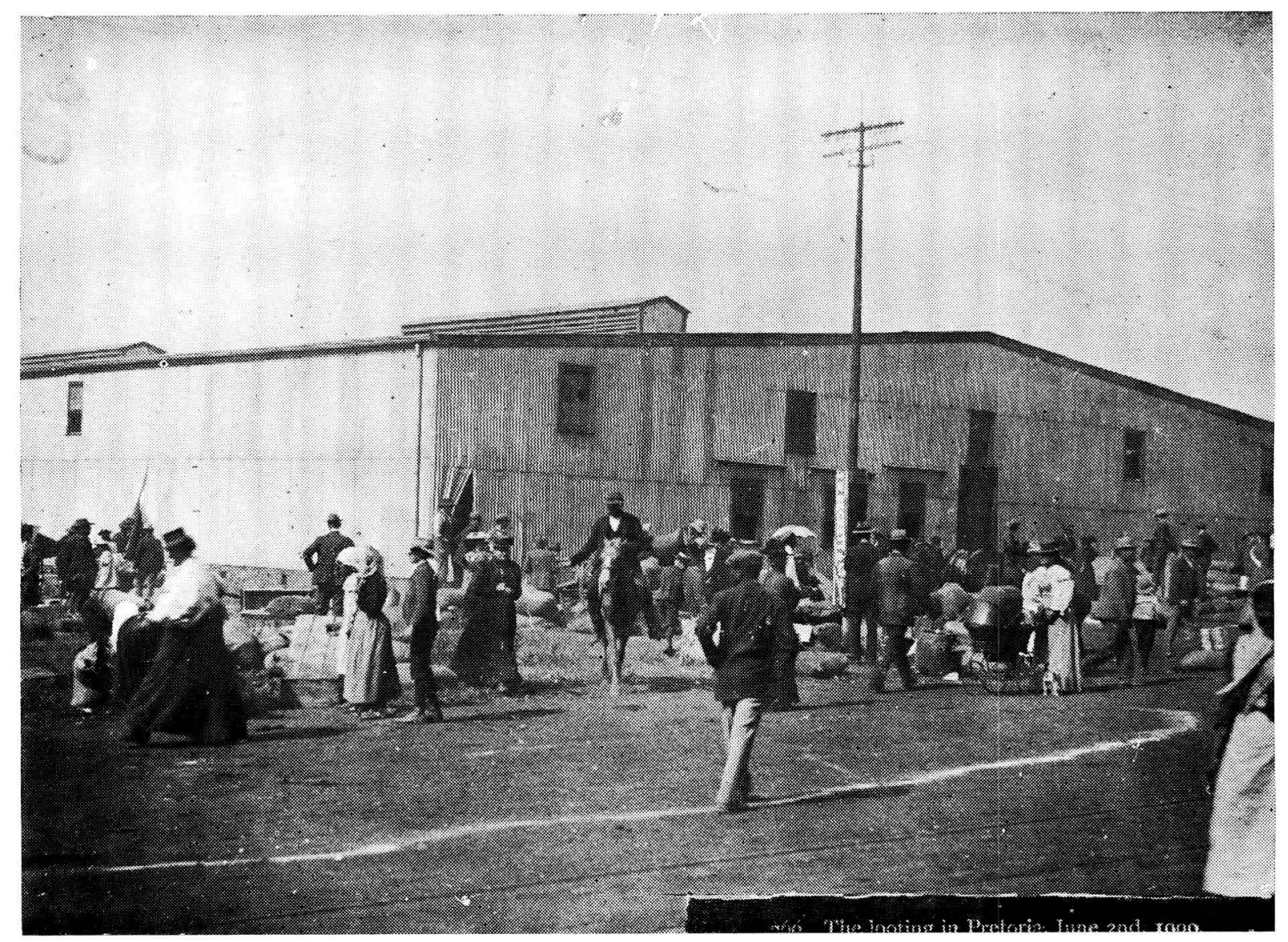

Plundering van die regeringsmagasyn op die hoek van Paul Kruger- en Visagiestrate

(Foto: Stadsraad, Pretoria)

boervrou. Ontstellend was ook in gerug dat die 3000 Britse soldate by Waterval uitgebreek het en (natuurlik vol wraakgedagtes) uit die noorde in aantog is na Pretoria.

Om sake te vererger het die skielike besluit van die regering om soos die Vrystaatse regering voor die val van Bloemfontein, na 'n veiliger oord te verhuis, bygedra om paniek te verhoog. ${ }^{16}$ Dit was weliswaar onder omstandighede die verstandigste om betyds voorsorgmaatreëls te tref en le sorg dat die Transvaalse regering nie in die vyand se hande val nie, maùr vir die publiek, wat nie oor hierdie stap inge: $g$ is nie, het dit amper na verraad gelyk. Staatsekretaris Reitz se seun, Deneys, moes van openlik vyandiggesinde bure verneem dat sy vader en die president voet in die wind geslaan het en dat Pretoria as ope stad aan die genade van lord Roberts uitgelewer was. ${ }^{17}$

Op 31 Mei 1900 het Johannesburg geval. Intussen het waarnemende kmdt genl L. Botha met die probleem geworstel hoe om Pretoria
Alaw dew lorstr.

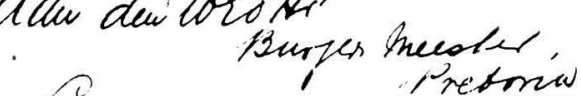

Lettende op de tocstand wang rust en orde beuraroi wonds. nu Cever eycudom te beschend tot her la atsere ty het heent

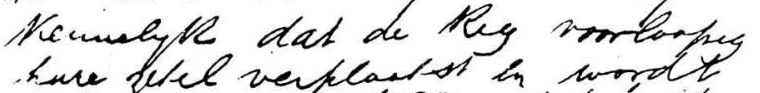

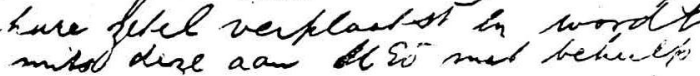

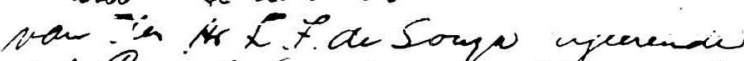
lod Commit feand ons ale mojelpe

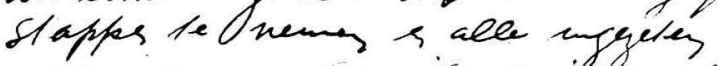
upterops am speciale deensty te versicely als andengind bon ust in orde te hancticiong im wele vieundeling is itceust doendec tarfis

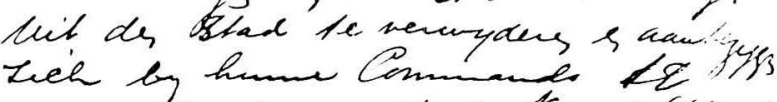

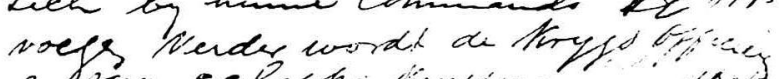

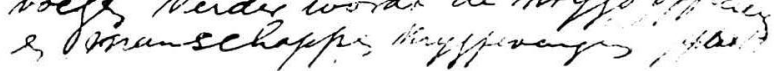




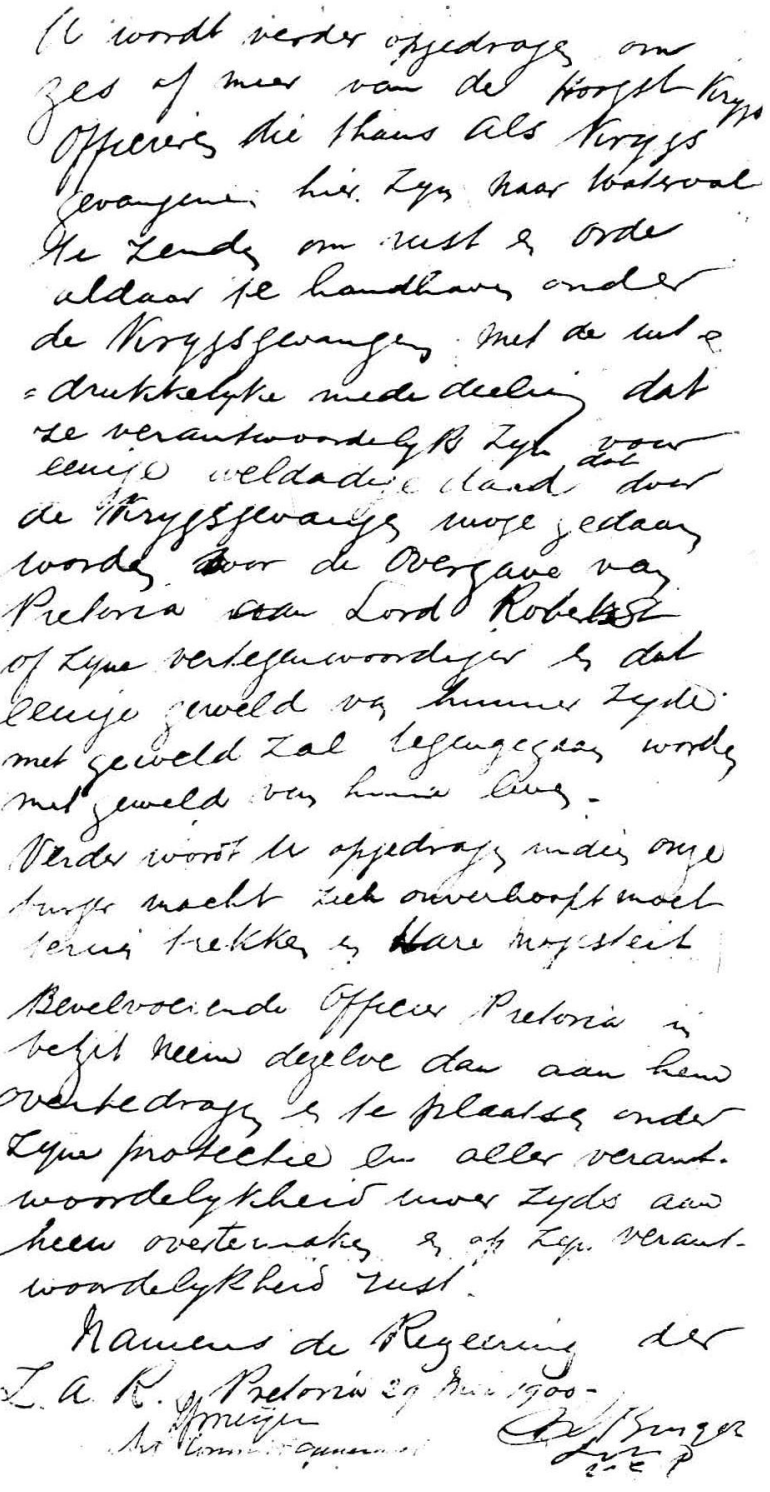

(Foto: Stadsraad, Pretoria)

Vise-president Schalk Burger se laaste opdrag aan die burgemeester van Pretoria gedateer 29 Mei 1900

te beveilig totdat die Britse troepe arriveer. Die finale beslissing oor die lot van die hoofstad het uiteindelik op sy skouers geval, ofskoon hy onder die moeilike omstandighede nie eintlik ' $n$ ander keuse gehad het nadat die Uitvoerende Raad nie verdedigingsmaatreëls getref het nie. Sonder behoorlike grofgeskut in die forte en terwyl sy burgers reeds orals tekens van oorlogsmoegheid getoon het, het hy ook besluit om Pretoria self nie te verdedig nie: 'n antiklimaks vir die vooruitsigte van menige strydende burger.

Die vyand is egter op strategiese punte tussen Johannesburg en Pretoria ingewag. Lede van 'n krygsraad wat by Irene byeengekom het, was volgens Naude baie verontwaardig oor die feit dat die Uitvoerende Raad nie betyds beter voorsorgmaatreëls getref het vir die verdediging van Pretoria nie. Inderdaad was die ondoeltreffende definisie van gesagslyne tussen krygsraad en regering noodlottig in krisistye, soos op die vooraand van die val van Pretoria wel die geval was.

Die ordeloosheid in Pretoria is aan bande gelê toe genl Botha op 2 Junie 1900 die reëlingskomitee, welke liggaam hy as te groot en lomp beskou het om sake te hanteer, afgedank het. Op dieselfde dag het hy 'n proklamasie uitgereik waarin hy verklaar het dat, aangesien die veglinie nou Pretoria se omstreke bereik het, hy die gebied as binne sy gesagsveld beskou. ${ }^{18} \mathrm{Om}$ orde en rus in Pretoria te verseker, het hy die administrasie opgedra aan 'n driemankommissie bestaande uit die plaaslike landdros, die plaaslike veldkornet P. F. Zeerderberg wat op grond van oorlogsdiens intussen tot kommandant bevorder is en Botha se persoonlike sekretaris, C. G. S. Sandberg.

Van die belangrikste take van die kommissie was om die orde te handhaaf en om manlike inwoners as wagte snags om die stad op te stel. ${ }^{19}$

Genl Botha se handjievol manskappe was reeds in hulle stellings: genl L. A. S. Lemmer in die koppies oos en noord van die Irenestasie en langs Sesmylspruit. Langs hom het genl De la Rey met ses kanonne Kwaggapoort beset terwyl aan genl S. P. du Toit opgedra is om by Kalkheuwel en Silkaatsnek lord Roberts se linkervleuel te beveg.

Op 3 Junie is lord Roberts uit Johannesburg met die verwagting dat daar vir hom groot teenstand voorlê alvorens die sterk gefortifiseerde Pretoria, hoofstad van die Transvaal, sou val. Van sy stafoffisiere was gekant teen sy besluit om Pretoria aan te val aangesien hulle gevoel het dat hulle kommunikasielyne te lank en onbeskermd was. ${ }^{20}$ Lord Roberts wou egter munt slaan uit die tydelik gedemoraliseerde Boeremag en besluit dus om teenkanting ten spyt, Pretoria aan te val. Hy beplan 'n direkte aanval met alle beskikbare manskappe en is later heftig gekritiseer oor hierdie skema in die uitvoering waarvan hy nie genoeg aandag gegee het aan die verowering van die spoorlyn oos van Pretoria 


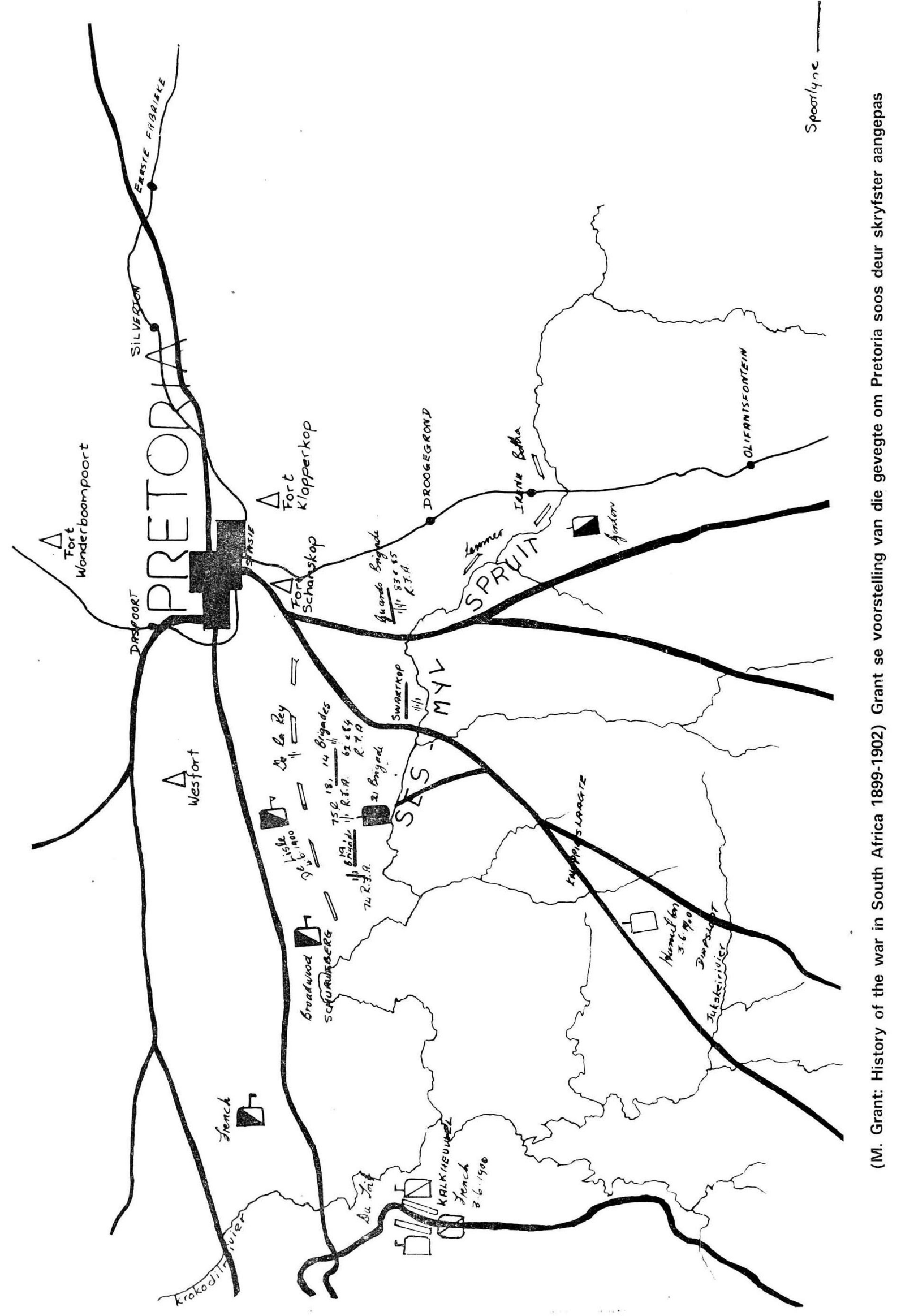


nie, want langs die weg is die Boeremagte vinnig ooswaarts ontruim.

Met It genl I. Hamilton in die agterhoede as reserwemag, het hy genl J. D. P. French saam met genl maj E. T. H. Hutton op sy linkervleuel ver wes om Pretoria laat verbytrek met die opdrag om die spoorlyn na die noorde van Pretoria af te sny.

Ongeveer 1400 uur op 3 Junie bots hierdie mag met die Boere se regtervleuel onder genl S. P. du Toit wat die randjies voor Kalkheuwel beset het. Die Boere was op hierdie stadium van die oorlog al reeds goed onderlê in die Britse gebruik om sodra sy hoofmag teenstand teenkom, die vyand met 'n omvleuelingsbeweging te probeer insluit. Hierdie taktiek is telkens gefnuik deurdat die Boere by die geleentheid ook weer hulle stellings vroegtydig verlaat het om maar weer elders posisie in te neem en sodoende die vyand in sy opmars te vertraag. Generaal French wou graag die Welgegunddrif oor die Krokodilrivier bereik voor donker en nadat die Boere oënskynlik verdwyn het, het 1 Brigade opdrag ontvang om voort te gaan. Die Boere, versteck in 'n digbegroeide kloof, is nie deur die verkenners ontdek nie. Toe die voorste patrollies van genl French die kloof binnegaan, het huile hul vasgeloop in kleingeweervuur wat hul momenteel paniekbevange laat terugval het. Genl French, wat met sy staf hier aan die front teenwoordig was, het aimal gelas om skuiling te soek. Daarna het 1 Bataljon Berede Infanterie onder kol E. A. H. Alderson, gesteun deur twee kanonne en die brigade van genl maj J. B. B. Dickson, op omliggende randjies stelling ingeneem en daarin geslaag om die Boere die aand uit hul posisies te dryí. ${ }^{21}$ Hierdie nag het genl French op die plaas Kalkheuwel, $30 \mathrm{~km}$ suidwes van Pretoria kamp opgeslaan terwyl genl Du Toit sy manskappe onttrek het in die rigting van Rustenburg.

Genl French het dus die volgende oggend sonder voorval die Krokodilrivier by Welverdiend oorgesteek en beide Kommando- en Silkaatsnekke beset. Op 4 Junie was genl French wes teenoor Pretoria opgestel en gereed om indien nodig, met sy volle mag die stad uit hierdie rigting aan te val.

Tot dusver het lord Roberts se opmars na Pretoria na skedule verloop. Die nag van 3
Junie was genl Ian Hamilton, op sy linkervleuel by Diepsloot, die hoofmag met die opperbevelvoerder se hoofkwartier by Leeukop en die regtervleuel onder brig genl J. R. P. Gordon $10 \mathrm{~km}$ verder in die rigting van Olifantsfontein. Van hier het sy verkenners die nag vasgestel dat die Hennopsrivier, indertyd meer bekend as Sesmylspruit, swak verdedig is. Vroeg op 4 Junie is Gordon se brigade oos van die Germistonpad op die aanval. Genl Botha se linkervleuel wat veral gekonsentreer was om Irenestasie, het die aanval argeweer en hul posisies behou. ${ }^{22}$ Elders langs die Sesmylspruit was die lyn egter swak verdedig sodat kol St. G. C. Henry sonder ongeval die Wierdabrug oor Sesmylspruit kon kruis. Gordon was egter verplig om sy opmars voort te sit langs 'n omweg want blykbaar het die burgers by Irene in hui posisies gebly tot die aand. Alvorens hulle na Pretoria teruggeval het, is die plaaslike spoorbrug opgeblaas.

Intussen is die Britse vloot se 12 ponder-kanonne in posisie gebring en artilleriste het, met fort Schanskop voor hulle, die eerste bomme in die rigting van Pretoria afgevuur. Nadat die eerste paar duidelik geen reaksie uit die fort gelok het nie, is daar heeltemal met reg tot die gevolgtrekking gekom dat die fort onbeset gelaat is. Daarna is die, vir die kanonniers onsigbare, Pretoriastasie gebombardeer om te voorkom dat die Boeremagte per trein ontruim word.

Die bomme het oënskynlik nie veel skade aangerig nie. Staatsprokureur Smuts het met behulp van 'n kommando 'n ietwat onwillige bankbestuurder verplig om die kontant en goudstawe van die Staat aan hom te oorhandig. Tussen bomskerwe deur is die goud in spoorwegwaens gelaai en ooswaarts versend en so is die fondse wat die oorlog nog maande later moontlik gemaak het, gered. ${ }^{23}$

Die hoofmag van lord Roberts het ook ongedeerd die Sesmylspruit deurkruis. Toe manskappe van 18 Brigade egter op die kruin van Swartkop te voorskyn kom, is hulle onverwags heftig gebombardeer deur genl De la Rey se burgers in die Kwaggaspoort. Met artillerieversterking kon hulle die Boere se kanone die swye oplê sodat dit teen 1300 uur vir lord Roberts geleë was om persoonlik die 
kop te bestyg om vandaar die geveg verder te hanteer. ${ }^{24}$

Intussen moes veral die linkervleuel van kol Henry, die Essex regiment, erg deurloop onder kleingeweervuur vanuit die Kwaggapoortrante totdat It genl C. Tucker se mag gearriveer het. Laasgenoemde het met verdrag al drie batterye van die Royal Field Artillery onder sy bevel in die veld gestoot teen De la Rey se manne.

Lord Roberts het genl I. Hamilton se reserwemag wat om 1400 uur via 'n drif op sy linkervleuel die Sesmylspruit deurkruis het, nou ook in die veld gestoot. Die hoë randjies waarop die Boere verskans was, sou nie sonder groot verliese met ' $n$ infanterie frontaanval ingeneem kon word nie. Lord Roberts herhaal toe sy beproefde resep en stuur 2 Kavallerie Brigade onder bevel van brig genl R. C. Broadwood om die Boeremagte te omvleuel. Die heuwelagtige omgewing tussen Mooiplaas en Schurweberg het die kavallerie egter verplig om ver wes by die Schurwebergpas deur te gaan met die gevolg dat hulle eers donker die aand 'n posisie agter Kwaggapoort bereik het. $^{25}$

Intussen het It kol H. de B. de Lisle 'n soortgelyke opdrag ontvang. Met sy 2 Mounted Infantry Corps, die West Australian en die New South Wales Mounted Rifles, het hy gebroke terrein aangedurf en 'n korter deurgang gesoek. Sy troepe het by 'n steil nekkie op Mooiplaas oorgegaan wat hulle onmiddellik wes van die Kwaggapoortrante gebring het. Genl de la Rey se manskappe moes in alleryl terugval sodat hulle in Maximkanon moes agterweë laat. Vlugtende voor die berede infanteriste het burgers op die westelike front Pretoria-Wes binnegegaan sodat koeëls van hul agtervolgers selfs in die dorp geval het. ${ }^{26}$ Hierna moes die oostelike vleuel ook die wyk neem toe die infanteriste met hul frontaanval slaag.

Om 1645 uur was It kol De Lisle op die heuwel wes van Pretoria wat sedertdien bekend staan as Proklamasieheuwel. Hiermee is die oorlog tot binne die poorte van Pretoria gebring. Ofskoon genl L. Botha eers laat die aand vanaf die front na Pretoria teruggeval het, was vir alle praktiese doeleindes, die geveg om die besit van Pretoria met De Lisle se sukses besleg.

\section{Oorgawe}

'n Wes-Australiese offisier It W. W. Russell Watson van Sidney wat onder bevel van $\mathrm{De}$

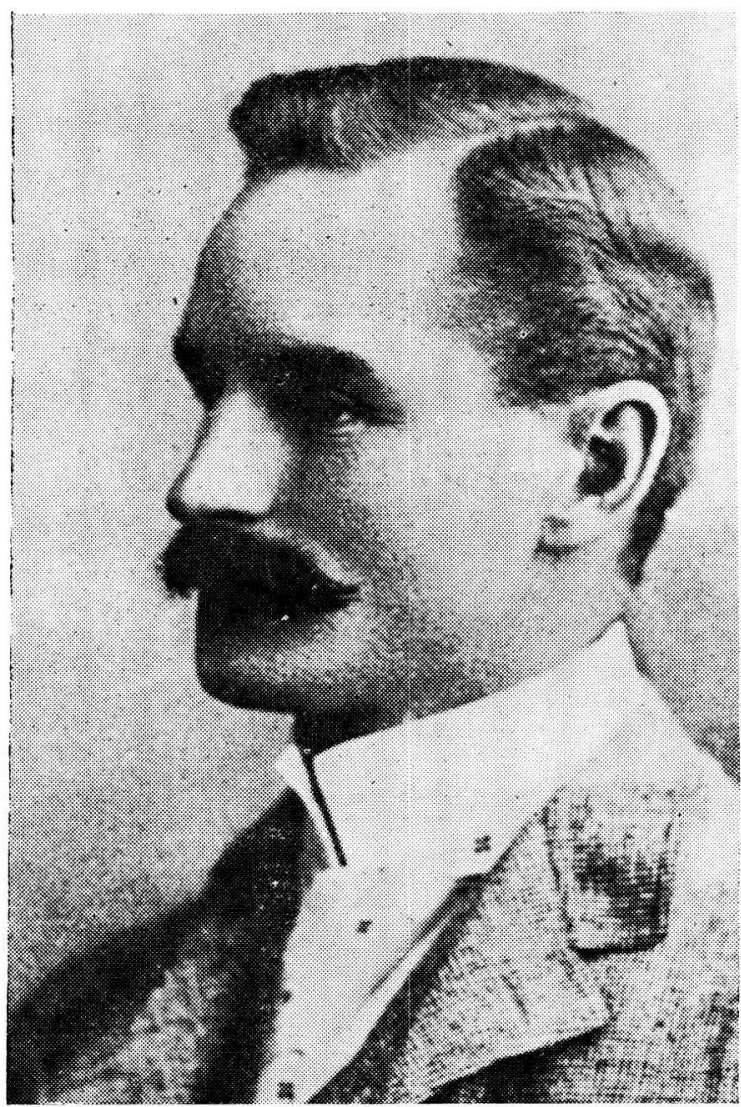

Lt kol H. de B. de Lisle wat op 4. Junie 1900 op oorgawe van die stad aangedring het

Lisle homself die dag onderskei het, het die volgende vertel oor wat verder gebeur het:

'Colonel De Lisle came up, beaming with delight, and said, "Now, lad, you have done so well, are you fit to take the white flag into the city and demand the surrender of the city in the name of lord Roberts and the British Army?" "Rather!" said I. So we tied a handkerchief on to a whip, and after saying goodbye to Holmes and the others, I started for the Landdrost of the capital with the white flag in the air alone and unarmed.

I had not gone far when I was stopped by an artillery man, so requested him to take me into town. He did so; but the Landdrost... the Burgomaster..., the Commandant-General, were still fighting on the hills about the city, so . . . he conducted me to CommandantGeneral Botha's private residence. ${ }^{\prime \cdots i}$ 
"By die huis was Robert Emmett die broer van generaal Botha wat nadat hy die offisier ontvang het, die heer Sandberg geskakel het. Dit was ' $n$ baie verbaasde Sandberg wat moes verneem, 'Sandjie, hier is ' $n$ Australiese offisier by ons met 'n boodskap van lord Roberts. Een van ons burgers het hom glo die pad beduie.'

Sandberg het self ' $n$ moeilike dag of twee agter die rug gehad. Op een stadium het hy berig ontvang dat ' $n$ hele kommando besig was om die regeringsmagasyn te plunder. Vol verontwaardiging het hy die mans wat die kosvoorrade geplunder het, verjaag deur hulle daarop te wys dat daar nog talle vroue en kinders sonder kos in Pretoria sal agterbly.

By die Botha's gekom, het hy dadelik 'n boodskap aan die generaal gestuur. ${ }^{28}$ uitgesien na die stem van 'n Creusot uit een van die forte om Pretoria, om die vyandelike grofgeskut te beantwoord. Namate die dag ten einde gesnel het, het dit vir hulle duidelik geword dat geen kanonvuur vanuit die forte die gesag van die Britse artillerie sou betwis nie. In elke fort het slegs een manskap oorgebly om die fort aan die oorwinnaar af te gee. Vir hulle wat dae agtereenvolgens vegtend en vlugtend in die rigting van Pretoria teruggeval het, vol moed dat die hoofstad van Transvaal nie sonder geweldige verliese deur die vyand beset sou word nie, was dit 'n groot teleurstelling. J. F. Naude herinner hom later die volgende gewaarwording gedurende die dag:

'Hier bereikte die moedeloosheid haar hoogste graad. De zon ging onder en duisternis daalde op Pretoria; alzoo ver-

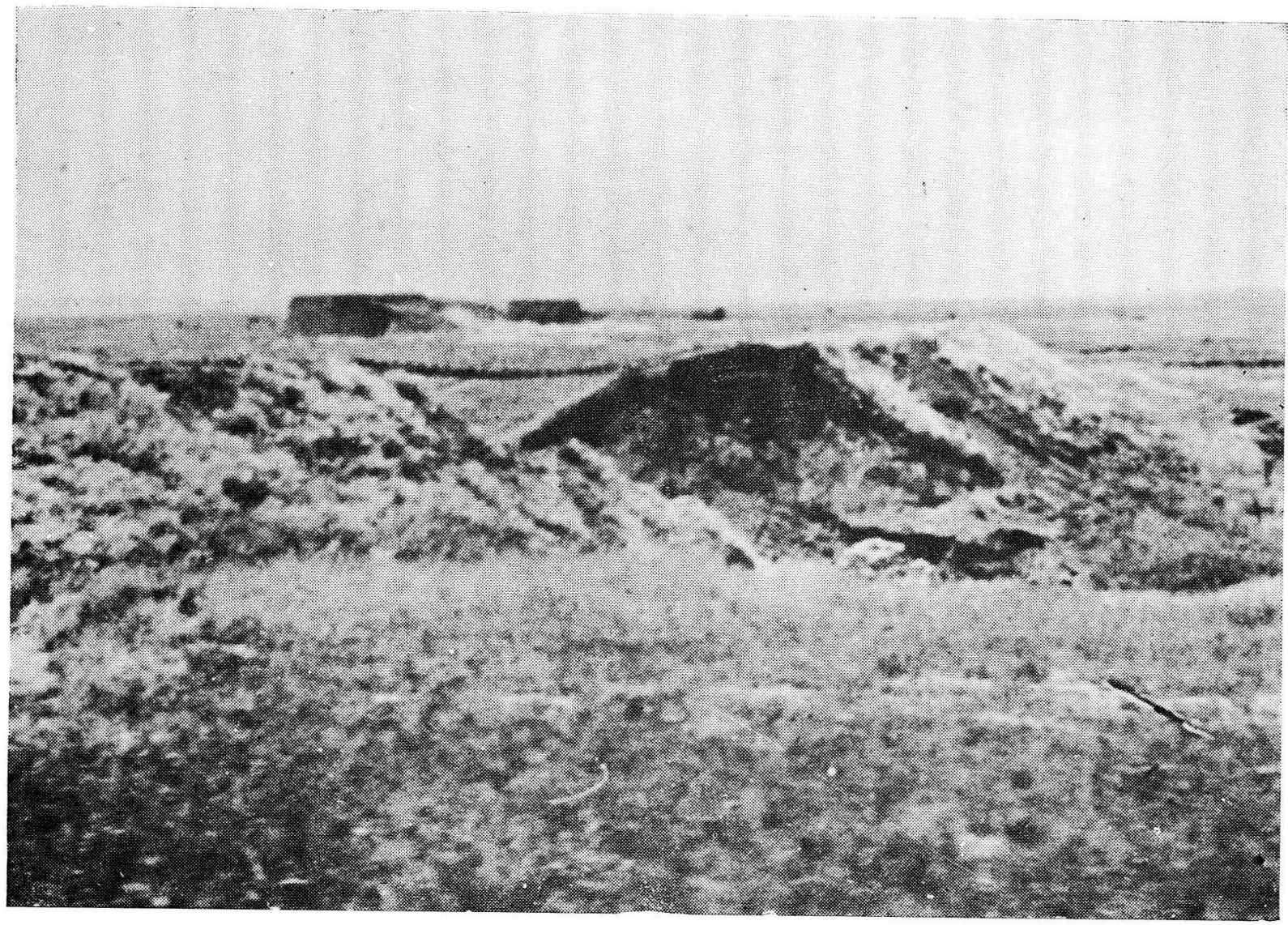

Spoorbrug by Irene deur die Boeremagte opge jlaas alvorens hul die gebied moes ontruim.

Intussen het die Boeremagte onder genl Botha by Irene hul posisies sterk verdedig. As die een lidietbom na die ander tussen hulle bars en die geel stofdampe al wat kos en water is bevlek en dus onbruikbaar maak, het hulle van vroeg die oggend al afwagtend dween de laatste vonk van hoop in menig Burgers hart en daalde de donkere moedeloosheid daarin neder." ${ }^{\prime 29}$

In Pretoria self kon die inwoners die dag kanongebulder en kleingeweervuur aanhoudend hoor. Tot hul ontsteltenis het bomme agter 
Scientia Militaria, South African Journal of Military Studies, Vol 5, Nr 3, 1975. http://scientiamilitaria.journals.ac.za

He the mansezen, Bunger. Sneestero, or Snaya, "Commipions \& Peace $x$ order, here $\xi$ hey to siltimate to the Officer Commanding the Bir tish farces near Retaina: (1) That our snititany ontrasition have retive from Pretaria;

(2) that we as head of the Cinit anding herely hand over the trin of Pelaice into your chayge-;

(3) Orr Shecial Police are gnmaing therests of heace ordeer here, and mill remain on dan till zom decide othermase.

the seynest ymu tiridly in the first instamee to haing as omall a farce in Pretaria as in Compratiste mith safets.

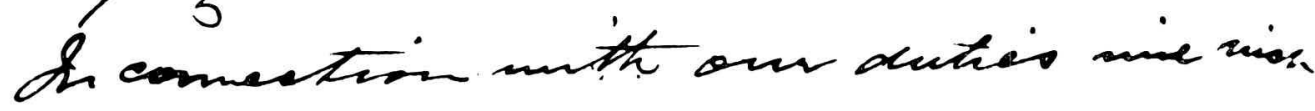
to drum yom altentiow the fack the

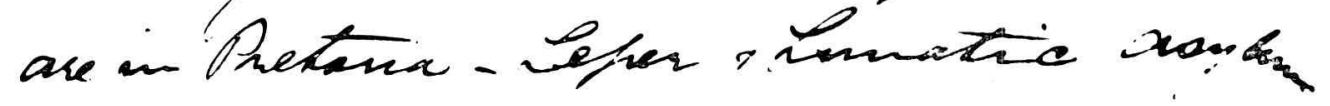
forten inimance g which atepn munthe tatem, ni case tho mandens dee ide to leacue.

34 

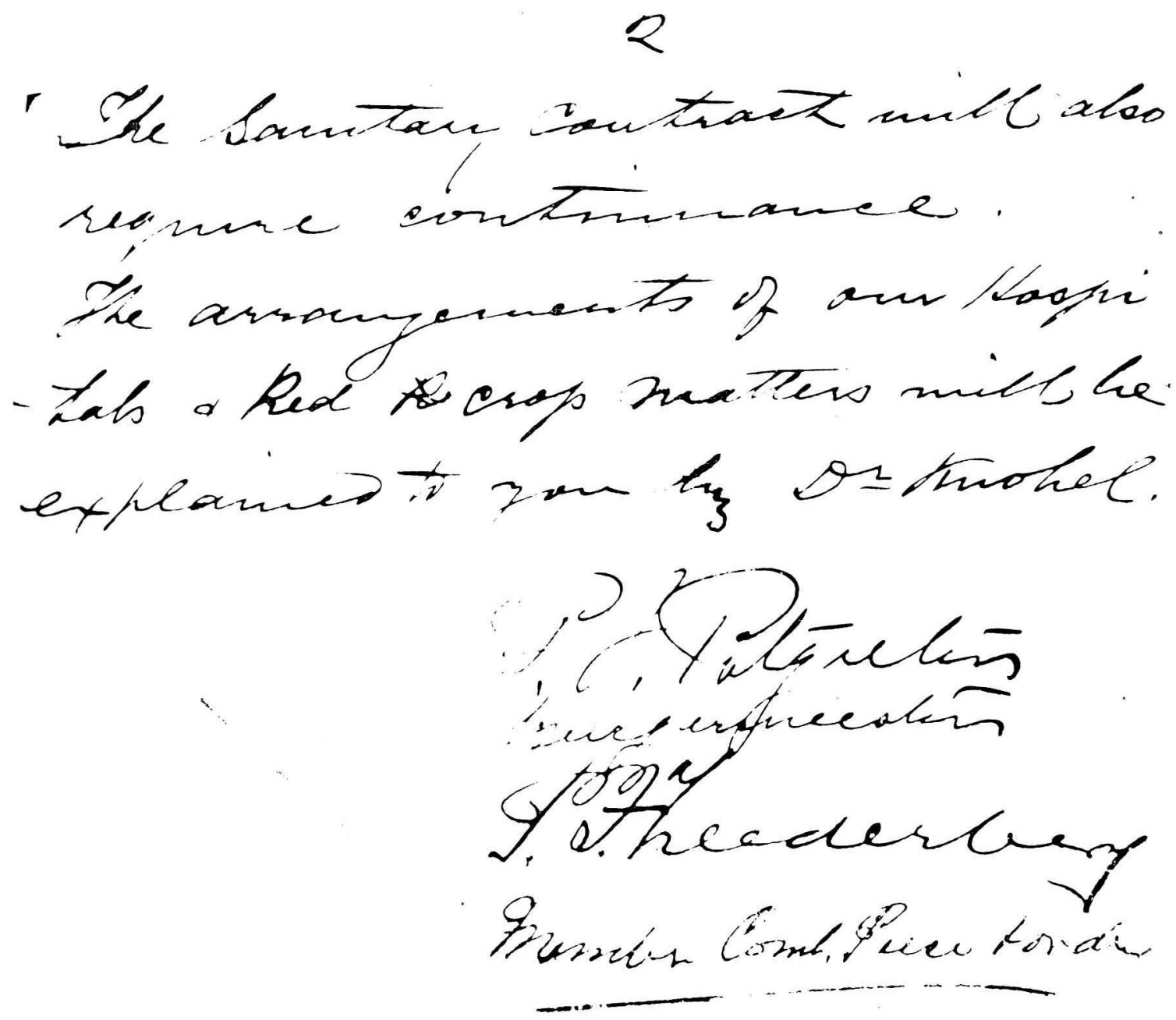

(Foto: National Army Museum, Londen) Brief wat deur die burgemeester van Pretoria op 5 Junie 1900 aan lord Roberts in die omgewing van die Fonteinedal oorhandig is.

Klapperkop en Skanskop naby sommige woonbuurte geval. Geel lidietstof het die stasie geverf terwyl die bewoners agter die forte ook by geleentheid onder skoot gekom het. Vir mense soos mevroue genl Joubert en Van Warmelo (laasgenoemde op Harmonie, digby Sunnyside) was dit 'n besige dag; 'n laaste kans om die kommissariaat van vegtende familielede uit eie haard aan te vul alvorens die Britse mag enige verdere kontak onmoontlik maak.

Die krygsgevangenes het weldra ook gewis hoe sake staan en die offisiere, vol moed oor 'n spoedige vrylating, geweier om hulle te laat verwyder na 'n ander oord. ${ }^{30}$

Volgens die Australiese offisier wat op 4 Junie met sy witvlag Pretoria binne gery het, het mev Botha hom op koffie en toebroodjies getrakteer gedurende die twee ure wat hy op die koms van waarnemende kmdt genl Botha gewag het. Die generaal het dadelik 'n krygsraad byeen geroep. Ofskoon lord Roberts se geledere reeds aansienlik uitgedun was omdat troepe garnisoendienste langs die spoorweg moes behartig, kon hy nog ruim 20000 man in die veld stoot teen Pretoria. Dit was ook genoeg om die stad mee te beleër met onsekere gevolge vir die ingeslote Boeremagte. Derhalwe is daar besluit om die Britse Opperbevelvoerder daarvan te verwittig dat die stad nie verdedig sal word nie en is daar om 'n wapenstilstand gevra ten einde vroue en kinders te verwyder. Uiteindelik is Sandberg, vergesel van kmdt Sarel Oosthuizen van die Krugersdorpkommando, afgevaardig om die brief aan lord Roberts te oorhandig.

Vergesel van die Australiese offisier, het hulle eers by $\mathrm{De}$ Lisle se kamp aangedoen en is van daar na lord Roberts. Dit was reeds amper middernag en vir Sandberg onmoontlik 


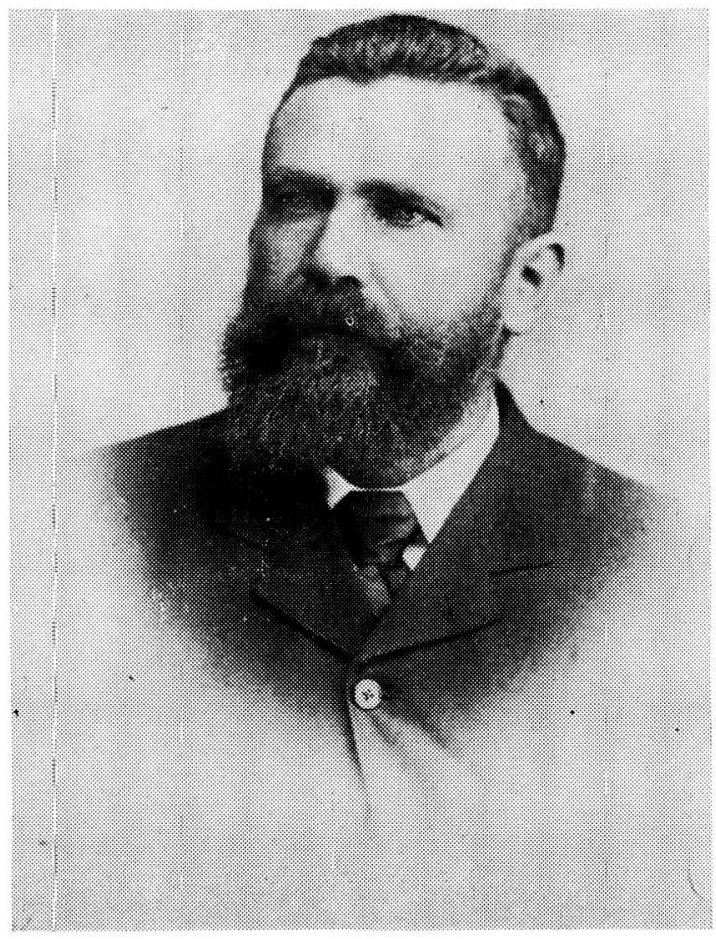

(Foto: Staatsargief, Pretoria)

P. J. Potgieter, burgemeester van Pretoria, 1900

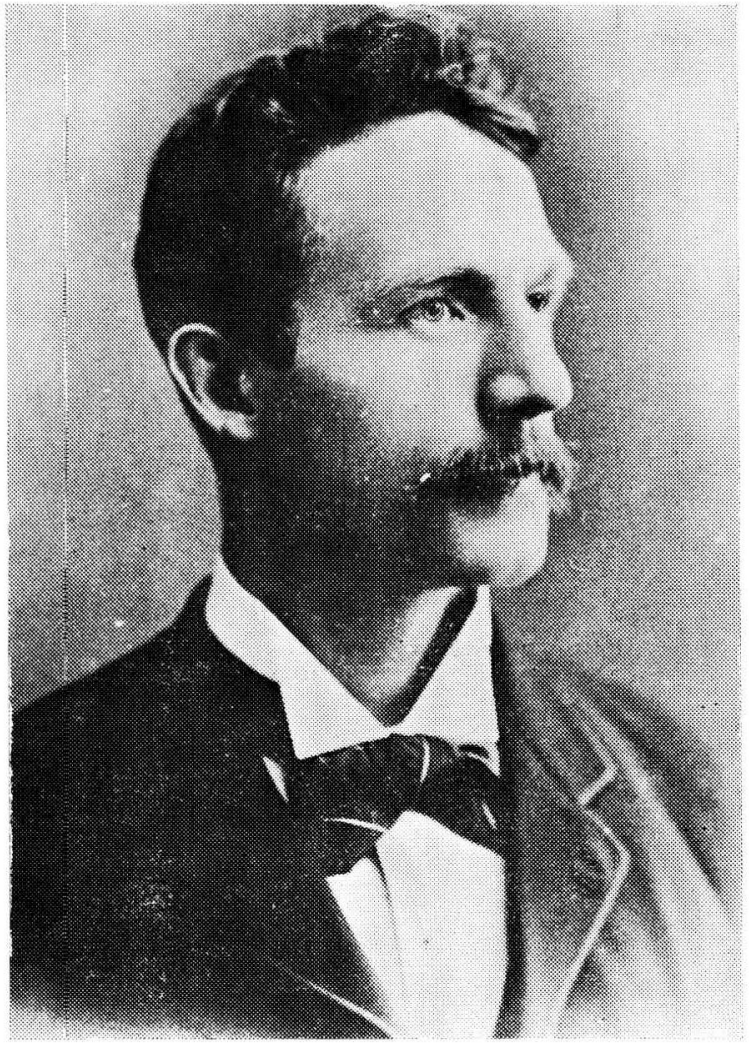

(Foto: Staatsargief, Pretoria)

C. G. S. Sandberg, sekretaris van kmdt genl Louis Botha, wat die laaste drie dae voor die val van Pretoria, lid van die driemanskapbestuur van die stad was om vas te stel presies waar hulle lord Roberts in sy veerwaentjie die nag aangetref het. Dit was waarskynlik in die omgewing van die latere Roberts Heights (tans Voortrekkerhoogte) in welke rigting die hoofmag afgetrek het nadat genl De la Rey sy stellings die middag ontruim het.

Terwyl genl Botha se brief aan die Britse Bevelvoerder oorhandig is vir beantwoording het Sandberg en sy rinetgesel hulle verkluimde liggame hierdie winternag verwarm om ' $n$ vuurtjie van die Britse wagte..$^{31}$ Dit was in die vroeë oggendure dat genl Botha verneem het van Roberts se eis om onvoorwaardelike oorgawe van die stad. Hy sou Botha 1000 uur die volgende oggend te woord staan maar die Boeregeneraal was die mening toegedaan dat in lig van lord Roberts se besluit, so ' $n$ byeenkoms geen doel kon dien nie. Lord Roberts het waarskynlik algehele oorgawe van die Transvaalse magte in gedagte gehad, maar die Boereleiers sou nog maande hierna die Britse besetting van hul gebied betwis. Botha en sy kommando's het die nag Pretoria ontruim en hulle na Eerste Fabrieke begewe. Met die slag van Sesmylspruit het hulle twee Britse manskappe gedood en 25 gewond. ${ }^{32}$

Dinsdagoggend 5 Junie 1900 is deur die ingesetenes van Pretoria en omgewing met gemengde gevoelens ingewag. Burgers wat hulle nog in die stad bevind het, het inderhaas ooswaarts uitgewyk. In die Sentrale Gevangenis in Pretoria waar die Natalse en Kaapse soldate van die Britse leër gevange gehou is, het die nuus dat lord Roberts se magte rondom Pretoria gereed staan om die stad in te neem, ook rugbaar geword. Weldra was hulle op vrye voet en het jillend van blydskap die stad ingevaar om sy koms af te wag. Terwyl die burgemeester, P. J. Potgieter na die Fonteinedal vertrek het om die stad formeel aan die Britse leër af te gee, het Sandberg die polisieoffisier, S. H. Van Diggelen, gelas om staatsgeboue in die dorp aan die Britte uit te wys. ${ }^{33}$ Hiermee het die driedaagse bestuur van die stad onder die driemanskap dan ook tot ' $n$ einde gekom.

Om negeuur die oggend het die hertog van Marlborough en die joernalis, Winston Churchill, wat in Desember 1899 uit die Staatsmodelskool, waar hy krygsgevangene was, ontsnap het, by die krygsgevange offisiere in die staatsmodelskool opgedaag met die goeie nuus dat Pretoria geval het. Die vol- 

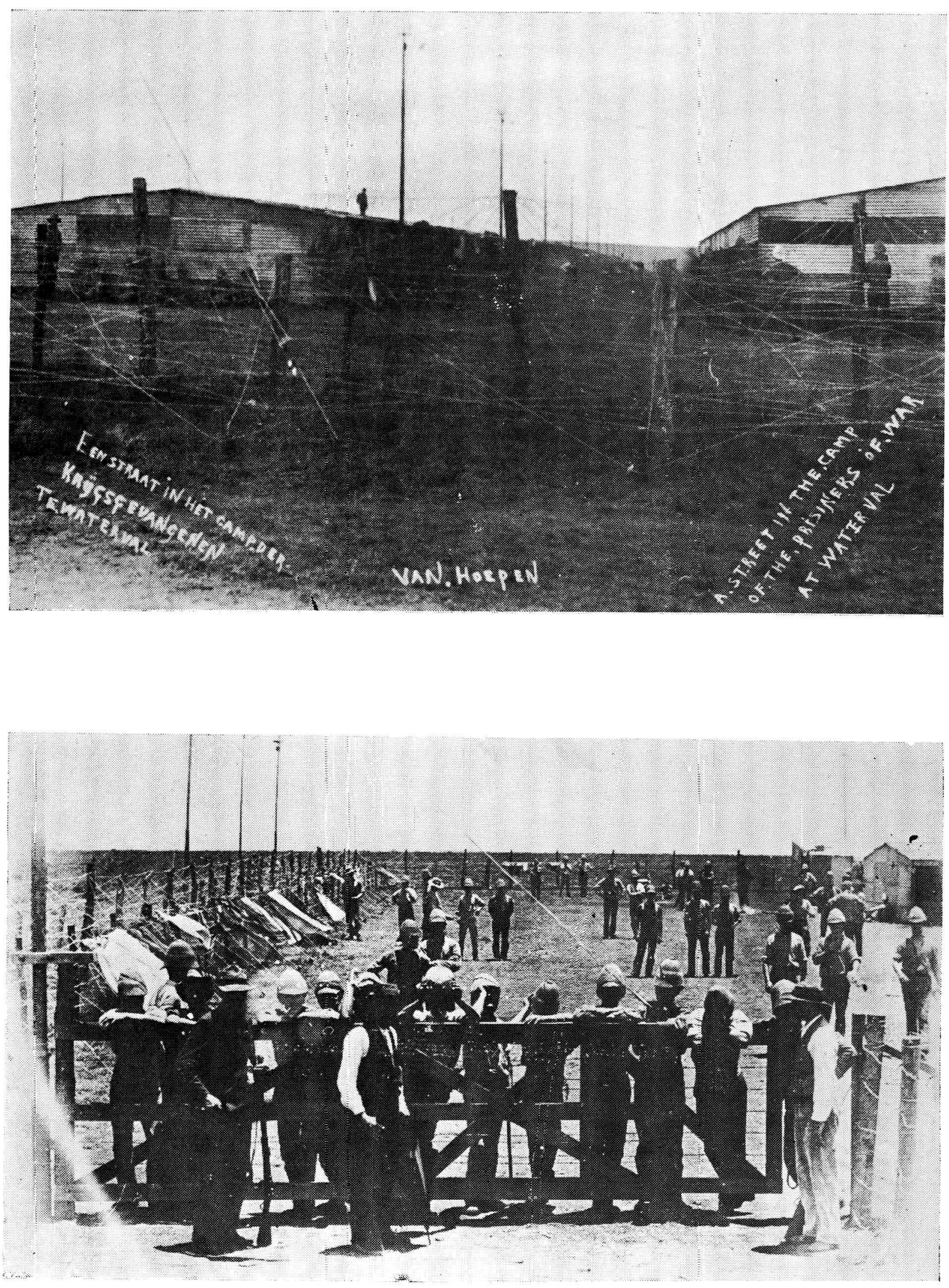

(Foto's: Staatsargief, Pretoria)

Krygsgevangenekamp by Waterval 
gende dag is die drieduisend verheugde gevangenes te Waterval ook daarvan in kennis gestel waarna hulle gou bordjies verhang het met die paar wagte wat hulle nog bewaak het. ${ }^{34}$ Genl De la Rey, wat genl French se opmars na die noordelike spoorlyn probeer stuit het, moes uiteindelik voor die getalleoorwig vlug. So was die pad na Pretoria vanuit die noorde ook gebaan vir die Britse troepe.

\section{Lord Roberts in Pretoria}

In hierdie laaste ure alvorens lord Roberts in Pretoria aangekom het, het enkele burgers, soos Sandberg tot oormaat van ramp uitgevind dat daar in Pretoria nie meer een perd te vinde was nie. Enige dier wat die vorige nag onbewaak moes deurbring, het wel 'n nuwe eienaar gevind. Onder diegene wat blykbaar op hierdie wyse vervoer 'opgekommandeer' het, was Deneys Reitz wat in sy herinneringskrif sy persoonlike ervarings verhaal ${ }^{35}$ Sand- berg het uiteindelik teen 1200 uur die middag op ' $n$ versukkelde dier uit Pretoria ontsnap. Met baie mooipraat en soebat kon hy die dier darem oorreed om hom na Eerste Fabrieke te neem waar hy weer by genl Botha aangesluit het.

Op Kerkplein en in die omliggende streke het belangstellendes en nuuskieriges van vroeg af reeds saamgedrom om ooggetuies te wees van lord Roberts se aankoms in Pretoria. Hier het ' $n$ grysaard met bedroefde gelaat gedink aan 1877 toe sir Theophilus Shepstone met ag staatsamptenare an vyf-en-twintig konstabels Transvaal geannekseer het; daar het ' $n$ plaaslike handelaar genoeglik geglimlag in sy baard omdat die dorp so sonder slag of stoot geval het: sy groot voorraadskuur nog ongeskonde, wagtend op Tommie se soldy. 'n Klein seuntjie met die vierkleurband om sy hoed, draai verontwaardig om as ' $n$ pas bevryde soldaat die kleure as aandenking opeis;

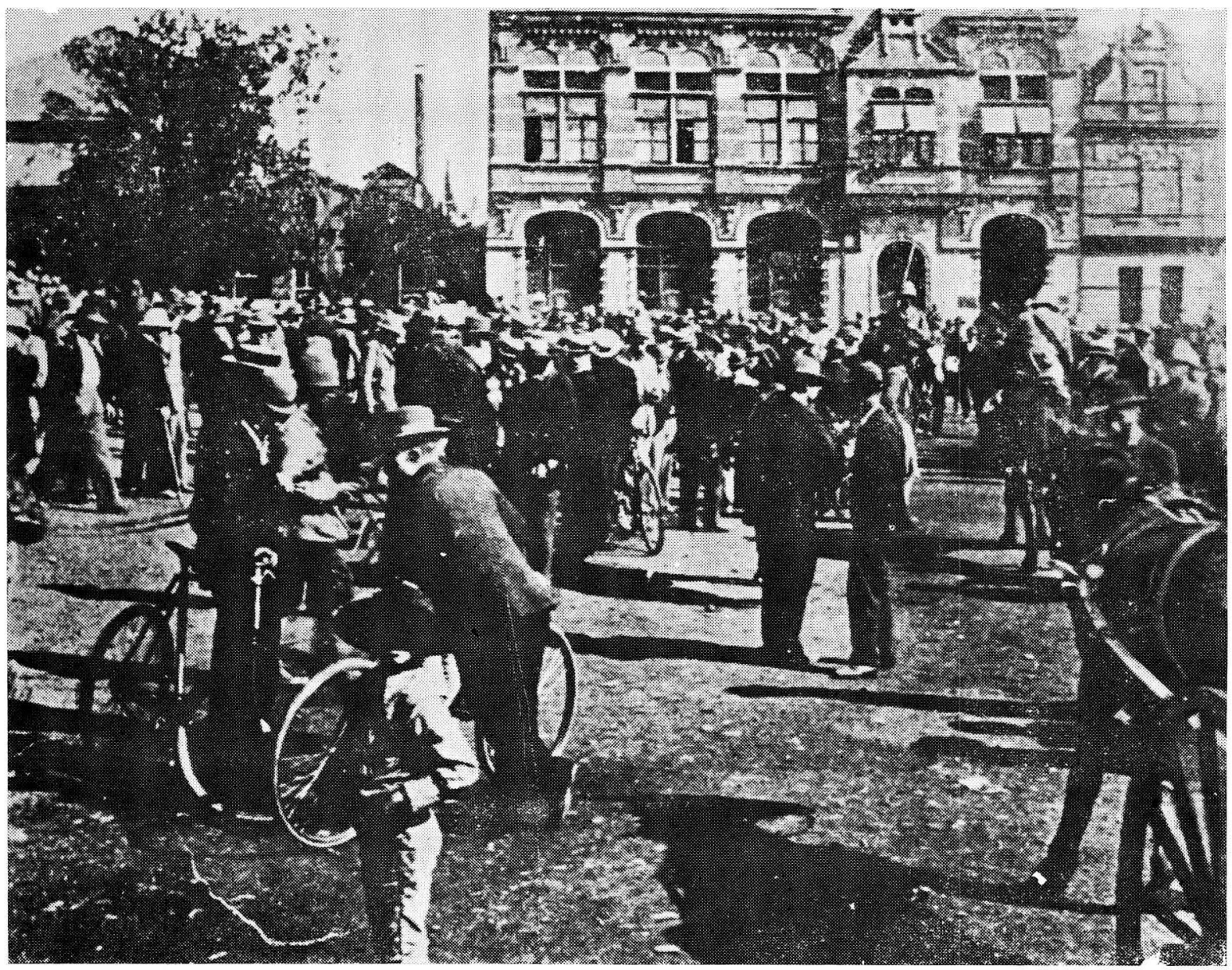

Nuuskierige inwoners wag die koms van lord Roberts af

(Foto: Staatsargief, Pretoria) 
dit terwyl hy hom vergaap aan die 3000 troepe wat na kerkplein marsjeer om lord Poberts se aankoms in die stad op luisteryke wyse te laat geskied. Johanna Brandt, ook met haar vierkleurband, vertel hoedat die Britse infanteriste honger en vermoeid langs die strate neergesak het om te eet of net te rus. 'Thank God, the war is over,' sê een. Mej Brandt en baie ander republikeine het anders gevoel oor die saak: 'Tommy Atkins, the war has just started. ${ }^{36}$

Om 1400 uur is alles voor die ou Raadsaal in Pretoria in gereedheid gebring. Die Union Jack, spesiaal deur lady Roberts aan haar eggenoot oorhandig, word op die Raadsaal gehys terwyl die orkes 'God save the Queen' speel. Om presies 1420 uur is lord Roberts c'eur sy soldate gesalueer. ${ }^{37}$

In Kerkstraat-Wes stap 'n paar ander soldate die eertydse presidentswoning binne. Met heimweë in die oë en stil gelaat word hulle deur Gezina Kruger ontvang. Woordeloos en magteloos sien sy toe hoedat hulle op haar privaatheid inbreuk maak om die interieur van die huis te fotografeer ${ }^{38}$ So word onbewustelik deur hierdie soldate in beeld vasgelê die laaste grepe uit ' $n$ era in ons geskiedenis wat op daardie oomblik verbygegaan het. $\mathrm{Na}$ die presidentswoning sou die Transvaalse president nooit weer terugkeer nie.

\section{Pretoria het geval.}

\section{Verwysings}

1. J. Ploeger en $\mathrm{H}$. J. Botha, Die Fortifikasies van Pretoria, pp 79 en 83 . Pretoria, 1968

2. EVR 559, No. 329 Uitgaande Stukke; De Volkstem, $8 \mathrm{Mei}$ 1900.
3. EVR 559, Brieweboek. Brief $7 / 5 / 1900$ van W. J. Fochens, Sekretaris van die Eerste Volksraad aan Ds. H. S. Bosman, aan die Staatspresident en aan die Tweede Volksraad; De Volkstem, $8 \mathrm{Mei} 1900$.

4. EVR 180. Notule van die Eerste Volksraad, 7 Mei 1900

5. EVR 180: Notule van die Eerste Volksraad, 7 Mei 1900, De Volkstem, 8 Mei 1900.

6. C. G. S. Sandberg. Twintig jaren onder Kruger's Boeren in voor en tegenspoed, p 309. Amsterdam, 1943; R. H. Kierman, General Smuts, p 31. Londen, 1948.

7. J. Ploeger et al, op cit, p 78; F. J. du T. Spies, Bladsye uit die militêre geskiedenis van Pretoria. Pretoria 18551955 , p. 102. Pretoria, 1955.

8. De Volkstem, 15 en $16 \mathrm{Mei} 1900$

9. De Volkstem, $26 \mathrm{Mei} 1900$.

10. Ibid., 15 Mei 1900 .

11. LA 681/48, Uitvoerende Raadbesluit Art 86, van $25 \mathrm{Mel}$ 1900.

12. SP Engelbrecht, e.a., Eeufees - Album. Pretoria se eerste eeu in beeld, p 73. Pretoria, 1952; Sandberg op cit, p 310.

13. J. F. Naude, Vechten en vluchten van Beyers en Kemp "Bôkant" De Wet, p 108. Rotterdam, 190.

14. H. D. J. Bodenstein, Was generaal Botha in 1900 'n verrader?, p 65. Pretoria, 1916.

15. S. P. Erggelbrecht e.a., op cit, p 74; Sandberg, op cit, p 312.

16. Johanna Brandt, Die kappie kommando, $\mathrm{p}$ 12. Pretoria, 1913. D. Reitz, Commando, P 109.

17. Ibid.

18. F. J. du T. Spies, op cit, p 103

19. Sandberg, op cit, p 312 .

20. L. S. Amery, The Times history of the war in South Africa 1899-1902, vol IV p 153. Londen, 1906

21. History of the war in South Africa 1899-1902 compiled by direction of His Masjesty's Government, pp 96-97. London, 1908

22. Amery, op cit, p 157; Naude, op cit, p 108

23. Kiernan, op cit, p 31

24. Official History of the War in South Africa 1899-1902, op cit, p 98; Amery, op cit, p 157.

25. Amery, op cit $p$ 157; Official History of the War in South Africa, op cit, p 101.

26. Ibid, p 101; Louis Cresw:cke, South Africa and the Transvaal War, vol V, p 188. Cape Town

27. Ibid, p 189.

28. Sandberg, op cit, p 315

29. Naude, op cit, p 110

30. Official history of the War in South Africa, op cit, p 102.

31. Ib.d, p 541.

32. Sandberg, op cit, p 318.

33. Engelbrecht, e.a. op cit, p 70; Official history of the war in South Africa, op cit, p 102

34. Reitz, op cit, p 111; Sandberg, op cit, p 318

35. Brandt, op cit, pp 36-37.

36. Engelbrecht, e.a. op cit, p 75; Reitz op cit, p 102.

37. Creswicke, op cit, p 190; H. H. Wilson, With the flag to Pretoria, Vol II, p 673. London 1901. 